\title{
SUPPORTIVE THERAPY: AN OPTION TO ENHANCE HOST IMMUNITY AGAINST COVID-19
}

\author{
AMRUTHA V. U. ${ }^{1}$, ARYA G. K. ${ }^{1}$, ARYA M. ${ }^{1}$, VANI VIJAY ${ }^{1}$, AKSHAYA KRISHNA ${ }^{1}$, ABHINANDH B. ${ }^{1}$, ANAND \\ CHANDRAN ${ }^{1}$, SREEJA C. NAIR ${ }^{*}$
}

\author{
${ }^{1}$ Amrita School of Pharmacy, Amrita Vishwa Vidyapeetham, AIMS Health Science Campus, Kochi 682041, Kerala, India
} Email: sreejacnair@aims.amrita.edu

Received: 08 Jun 2021, Revised and Accepted: 02 Aug 2021

\begin{abstract}
The threat posed by COVID 19 outbreak, which is considered to be a global pandemic, is immeasurably affecting all the communities worldwide. COVID19 is a zoonotic disease, which can affect birds, humans and, other animals. The emergence of this pandemic has been creating a tragic situation worldwide by affecting more people through human-human transmission. The burden (both healthwise and economic) placed by the disease is so huge that any measures to improve the current situation, to fasten up the recovery of already affected patients and, to reduce the risk of death and health deterioration should be considered. Vaccination, being the hope in the scenario, helps in preventing the condition to an extent, but in the absence of availability of a proper drug regimen to fight off COVID 19, the requirement of the need to find a system to control the severity of the infection is a necessity Nutritional supplementation helps in boosting up the immune system especially, vitamins like vitamin C, Vitamin D, Zinc, Omega 3 fatty acids, etc. They also exhibit established immunomodulatory, antiviral as well as anti-inflammatory effects. Pieces of evidence have also highlighted the importance of supportive therapy using nutrient supplements in covid patients as it helps in prominent decreasing of SARS CoV2 load of the virus and also significantly reduces the hospitalization period. Hence the nutritional levels of each of the infected person must be assessed before initiating the anti-viral therapy. The search criteria used were PubMed, Medscape, google scholar, etc. The keywords used to search were COVID 19 Supportive therapy, Vitamin D, Vitamin C, Nutrient supplementation, Host immunity, etc. The range of years is between 1978 and 2021.
\end{abstract}

Keywords: COVID 19 supportive therapy, Vitamin D, Vitamin C, Nutrient supplementation, Host immunity

(C) 2021 The Authors. Published by Innovare Academic Sciences Pvt Ltd. This is an open-access article under the CC BY license (https://creativecommons.org/licenses/by/4.0/) DOI: https://dx.doi.org/10.22159/ijap.2021v13i5.42341. Journal homepage: https://innovareacademics.in/journals/index.php/ijap

\section{INTRODUCTION}

Towards the end of 2019, the novel coronavirus was identified as 2019-nCoV at Wuhan, China, and WHO named it Corona Viral Infectious Disease 2019 or COVID-19. This is the third coronavirus outbreak that we have been witnessing. The first two were Severe Acute Respiratory Syndrome Corona Virus (SARS-CoV) in 2002 and Middle East Respiratory Syndrome (MERS-CoV)in 2012 [1]. Coronavirus came up in 2003 in China was an epidemic that consequently resulted in SARS and subsequently, in 2012 in Saudi Arabia, it led to Middle East Respiratory Syndrome (MERS). While comparing the current pandemic with the SARS-CoV in 2002, the present SARS CoV-2 is highly pestilent as well as virulent and affected the whole world [2]. Interpersonal transmission of SARSCoV-2take place mainly through droplet infection developed as a result of coughing, sneezing, etc. and this is highly comparable with the outspread of influenza. Transmission can, yet al. so occur when a person is purulent with or without the sign of infection is near a normal person [3].

\section{Structure of COVID-19 virus}

These viruses are usually spherical or pleomorphic $[4,5]$. The rounded envelope of the virion consists of Membrane glycoprotein, small envelope glycoprotein, and protruding crown-like spike glycoproteins. The name corona (means 'crown' in Latin) was obtained from these spike glycoproteins and it will help to ease the entry of the virus into the host cell. Membrane and small envelope proteins mediate the viral assembly and as well as maintain the structural shape of the envelope. Some coronaviruses also encode for another type of glycoproteins called haemagglutininacetylesterase glycol proteins on their envelope [6]. Inside, it has a large genome with positive-stranded Ribo Nucleic Acid (RNA) covered by helical capsids made up of nucleocapsid phosphoproteins; together they form the ribonucleoprotein core. Other than virus entry, the spike proteins play a critical role in determining the viral host range and tissue tropism and are also involved in mediating the host immune response. These spike proteins are cloves like structures made up of two subunits S1 and $\mathrm{S} 2 . \mathrm{S} 1$ is the head of the spike and is involved in binding to the receptor present on the host cell surface for viral attachment and S2 which forms the stem of the spike and is responsible for the fusing of virus membrane with host cell membrane followed by injecting the viral genome into the host cells. Species-specific interactions between these glycoproteins are facilitating the localization of viral assembly at the intermediate compartment between the endoplasmic reticulum and Golgi apparatus [7, 8].

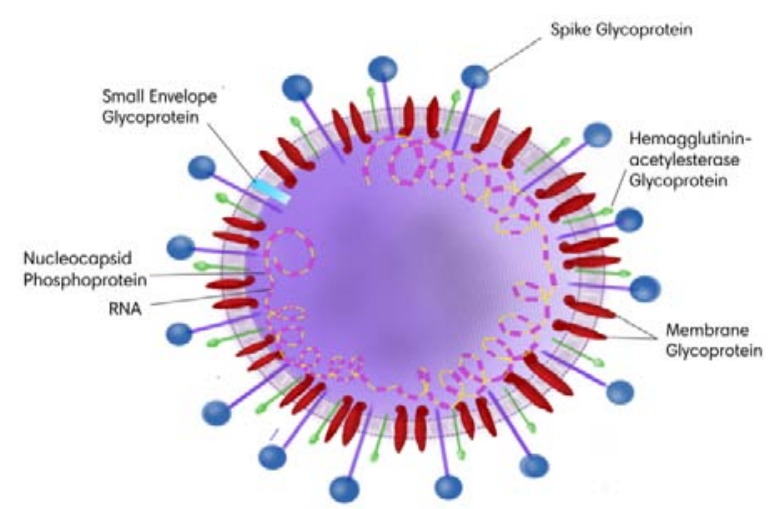

Fig. 1: Structure of COVID-19 viruses [9]

\section{Mode of transmission}

The virus can spread mainly via droplets released when the infected person cough or sneezes. The major problem is that these droplets can travel at a distance of 1-2 meters and they may get deposited on different surfaces. Anyone who inhales the droplets or touching the surface which contains these droplets, and then touching the eyes, nose, and mouth afterward may get infected. This virus can survive for several hours on the surfaces unless it is destroyed immediately by disinfectants such as sodium hypochlorite, hydrogen peroxide, etc. [10]. Both symptomatic and asymptomatic patients can transmit the disease to other people. Studies have shown that the viral loads for both asymptomatic and symptomatic patients are the same [11]. 
Based on some scientific evidence, on $9^{\text {th }}$ July 2020 WHO has announced that COVID-19 maybe get transmitted through the air. It may usually happen in the case of specific settings or circumstances where aerosols are generated from the supportive treatment. However, the latest data reveals that the virus also has the potential to spread through the air, fomite, fecal-oral, blood, mother to child, and animal to human. Still WHO continues to recommend precautions for airborne transmission since it is a major source of transmission [12].

\section{Pathophysiology}

The virus will enter into the host cell through endocytosis and the process is mediated by the spike glycoproteins. Then it will undergo membrane fusion with the help of membrane glycoproteins. After uncoating, the virion will release its RNA. Once it is released, it will go to the nucleus and undergo replication, followed by transcription and translation for the biosynthesis of viral proteins. Afterward, the viral assembly will occur at the endoplasmic reticulum Golgi intermediate compartment. Finally, the new virions are made and released [13]. Coming to the pathophysiology, the SARS-CoV has a good affinity for Angiotensin Converting Enzyme-2(ACE2) receptors, and some studies have shown that SARS-CoV-2 (nCoV-19) also binds to the same $[14,15]$. ACE2 receptors are distributed in the lungs, kidney, heart, ileum, and bladder. But it is more expressed in lung epithelium [16]. The person who got infected with SARS-CoV-2 shows a wide range of symptoms from a mild cold to severe respiratory failure with multiple organ impairments. Innate immunity of the lungs is regulated by the epithelial cells, alveolar macrophages, and dendritic cells. Lung injury observed in many patients with SARS-CoV-2 can be matched with the binding of SARS$\mathrm{CoV}-2$ with the ACE2 receptors located in the lungs [17]. Occupying these receptors by the spikes of the virus results in ACE2 downregulation, which will further amplify the production of angiotensin due to the decreased conversion of angiotensin to vascular heptapeptide angiotensin 1-7 and can cause lung injury later [18]. Based on the reports from the immunological studies, the infected person with SARS-CoV-2 shows a remarkable reduction in the lymphocyte, especially in peripheral $\mathrm{T}$ cells. In the case of patients with severe Novel Coronavirus Pneumonia (NCP), their T cell count will become half of the lower limit of the normal range. Likewise, this irregular expression of T cell-associated mRNA can initiate Venous Thromboembolism (VTE). Thus, elder patients with the same disease were more possible to have poor immunity and which make them more prone to develop VTE. This viral infection can also cause the release of inflammatory cytokines such as Interleukin (IL)-6, IL-8, TNF-alpha, etc. $[19,20]$. Production of inflammatory cytokines in patients with severe NCP can also boost the development of VTE and this irregular blood clotting and thrombosis in turn results in a poor prognosis of the disease [21]. Infected people can also develop an acute myocardial injury. Blood Pressure and cardiac biomarkers levels will be high for patients admitted to the Intensive Care Units (ICU) than other patients. It might be related to the ACE2 receptors present in the heart. This myocardial injury can also result from the release of different inflammatory cytokines, respiratory depression, and decreased levels of oxygen in the blood due to SARS-CoV-2. COVID-19 patients with severe cardiovascular disease may result in an adverse prognosis [22]. The presence of ACE2 receptors in the stratified epithelium of the upper esophagus and enterocytes of the ileum might be the reasons behind the early gastrointestinal symptoms like diarrhea, nausea, vomiting, etc during COVID-19 infection [23]. The detailed pathogenesis of the coronavirus is as shown in fig. 2.

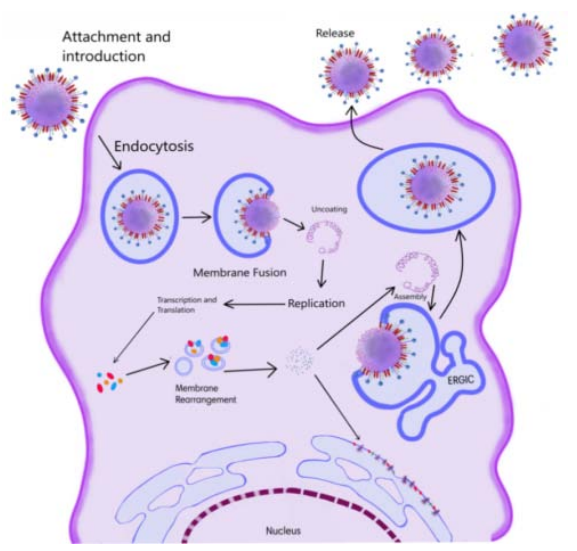

Fig. 2: Pathogenesis of SARS CoV2 infection [24]

\section{Epidemiology}

nCoV-19 has emerged in Wuhan, China, towards the end of December 2019. The geriatric population having an age group above $65 \mathrm{y}$ and the children below $8 \mathrm{y}$ were more prone to get infected. The increased death rate was also found in the case of older people, and the major reasons were multiple organ failures like respiratory failure, shock, and acute respiratory distress symptoms due to SARSCoV-2. A study conducted in two hospitals of Wuhan has taken the risk factors like older age, higher Sequential Organ Failure Assessment (SOFA) score, and the d-dimer value above $1 \mathrm{mcg} / \mathrm{ml}$ at the time of admission as part of the multivariable analysis. Cardiovascular disease, hypertension, and diabetes are considered for univariable analysis. From China, the disease has been spreading all over the world. According to the WHO statistics at the beginning of July 2021 more than 18.3 crore cases were reported worldwide, among them, nearly 2.95 crores were confirmed in India.

\section{Clinical features}

Persons who do not exhibit any symptoms and no variations in the radiographic images like Computed Tomography (CT) scans even though he/she is tested positive for the nucleic acid of nCoV-19 by Reverse Transcriptase Polymerase Chain Reaction (RT-PCR) is referred to as asymptomatic infections. Due to the absence of clinical symptoms and the lack of awareness, most asymptomatic people might not seek any medical support which can lead to quick transmission of the disease. People who have been infected with nCoV19 show a wide variety of symptoms ranging from mild fever to severe illness like respiratory failure. These symptoms may develop after 2$14 \mathrm{~d}$ of exposure. The severity of COVID-19 mainly depends upon various factors like age, body condition, and immune response of the patient and it can vary from person to person. The major symptoms of the coronavirus are categorized into four types, namely, mild, moderate, severe, and critical cases as shown in table 1.

Table 1: Symptoms associated with SARS CoV 2 infection

\begin{tabular}{lll}
\hline Stages & Characteristics & References \\
Mild & - Fever/chills \\
& - Maugh, Loss of appetite \\
& - Fatigue \\
Moderate & - Sore throat \\
& - Mild to moderate symptoms \\
Severe & - Shest images may show mild pneumonia \\
& - Significant lesions can be seen in chest images & {$[26]$} \\
Critical stage & - Severe respiratory illness like ARDS, shock, etc. along with multiple organ impairment(requires mechanical \\
& ventilation)
\end{tabular}




\section{Diagnosis, treatment, and prevention}

The extensive method used for the diagnosis of COVID-19 is RT-PCR (Reverse Transcriptase-Polymerase Chain Reaction). It involves the detection of SARS-Cov-2 RNA from the samples collected from the nasopharynx [29]. The mechanism behind the test is the reverse transcription of the viral RNA to the complimentary Deoxyribo Nucleic Acid (cDNA), and afterward, the amplification of few sections of the cDNA [30]. The test sensitivity depends on the time of testing respective to the virus exposure. Sometimes the test can give false-negative results, and it may be due to inadequate sample, specimen used for the sample collection, and the time of testing after exposure [31]. Mutations in the viral genome, sample collection technique, and samples with low viral load (mostly seen in the case of asymptomatic or people with mild signs and symptoms) can also result in false-negative results. The samples collected from the lower respiratory tract like bronchoalveolar fluid, are more sensitive than the samples collected from the upper respiratory tract (e. g.: oropharyngeal swabs). Other specimens are sputum, nasopharyngeal and nasal swabs. The presence of viral genetic material in the sample taken from the respiratory tract cannot be used to confirm the viability of the virus; hence RT-PCR is not that much efficient to predict if the person with the viral genetic material (RTPCR positive) can transmit the virus to others. Saliva can also be employed as a specimen, only after validation due to its lower sensitivity. The presence of the virus has also been detected in feces in certain cases but it is rare [32]. There are different types of serological tests to detect the humoral response to the SARS-CoV-2. Enzyme-Linked ImmunoSorbent Assay and chemical luminescence immunoassays (CLIA) are used to detect the antibodies of IgA, IgM, and IgG isotypes specific to different viral proteins in which the latter one has the highest sensitivity. The technique used for testing, immunity of the patient, tenure of symptoms, and antibody specificity are the factors that determine the sensitivity and specificity of the serological tests. The support laboratory tests like elevation in CRP, thrombocytopenia, high procalcitonin levels, etc., and abnormalities in imaging tests like chest x-rays and CT scans may show features of COVID-19, but they lack specificity when compared to other tests [33]. Treatment methods available for COVID-19 are antiviral therapy using remdesivir, ritonavir, danoprevir, favipiravir, and nefamostat, etc $[34,35]$. Antimalarial drugs like chloroquine or hydroxychloroquine along with the antibacterial drug azithromycin, can decrease the severity of symptoms. Interferons, monoclonal antibodies, and antiinflammatory drugs such as steroids can also be included in the treatment of COVID-19 [36]. Patients with mild to moderate symptoms only need supportive therapy to maintain the homeostasis and fluid-electrolyte balance etc. Mechanical ventilation and extracorporeal membrane oxygenation are used in the case of patients with serious symptoms to improve the condition [37]. The available preventive measures are proper hand washing, maintaining social distance, double masking, and vaccination. As of 2021 February, about seven vaccines have been enrolled in various countries and about 200 vaccine candidates are in the process of development. Vaccines are crucial tools in fighting against COVID 19. Safe and effective vaccines may change the situation; however, in the foreseeable future, should continue to wear masks, follow physicalsocial distancing, and must avoid crowds.

Supporting the antiviral therapy in covid patients with supplemental nutrient supply has highlighted advantages. COVID 19 high-risk category patients have been noticed with significant dietary deficiency of nutrient supplements [38]. It is also noted that elderly people are more liable to be nutrient lacking and immunosenescent, thereby more likely experiencing the risks of COVID 19 [39]. Therefore ensuring the adequacy of nutrients is equally important. The immunomodulatory as well as antioxidant properties of these nutrients like vitamin $\mathrm{C}$, vitamin $\mathrm{D}$, zinc, etc. helps in a prominent reduction in the viral load [40].

\section{The supportive role of nutrient supplementation in immune-} boosting

Once entered into the human system, the SARS CoV 2 virus initially binds to the epithelial cells of the alveoli, thereby activating the immune systems (innate as well as adaptive). The resulting cytokine release syndrome impairs the immune response of the host system and causes acute respiratory distress syndrome [41]. The condition is mainly relevant in the elderly group of people who are more prone to developing cytokine storms. The major inflammatory markers that are highly elevated in covid patients are interleukin 6 (associated with high mortality rates), interleukin 2, IL 7, tumor necrotic factor (TNF), etc., which can aggravate inflammation [42]. SARS, as well as MERS, are also associated with the over-activation of cytotoxic $\mathrm{T}$ cells, irregularities in histocompatibility complex 2 , and thereby prominent decline in natural killer cells, T lymphocytes, $B$ lymphocytes, etc. [43, 44]. The prominent nutrients that can offer immune-boosting effects include vitamins like vitamin A, vitamin B, vitamin $C$, vitamin $D$, and other nutrients like zinc, selenium, magnesium, omega 3 fatty acids, etc.

\section{Vitamin A}

Vitamin A is found to be the first recognized fat-soluble vitamin. It is essential for maintaining healthy vision, cellular growth and also plays a major role in enhancing the body's natural defense mechanism; hence it is called an anti-infective vitamin. Retinoic acid retinol, and retinal are the three active versions of vitamin A. Immune responses are primarily dependent on the availability of essential nutrients in the body. Pieces of evidence suggest that supplementation of vitamin $\mathrm{A}$ is associated with a reduction in morbidity and mortality in case of certain diseases like malaria, measles, Human Immunodeficiency Virus (HIV) infection, etc. [45]. A Diet low in vitamin A can render calves more susceptible to infections because the deficiency has resulted in reduced effectiveness of the bovine coronavirus vaccine [46]. Among children below the age of five, one of the leading reasons for mortality includes lower respiratory tract infections like bronchiolitis, pneumonia, etc. [47]. The majority of these deaths are due to malnutrition, poverty, and lack of resources. Vitamin A, otherwise retinol is engaged in the manufacture, development, and differentiation of cells in the lymph node, red blood cells, antibodies, as well as maintaining the integrity of epithelial cells. Due to the proven potency in safeguarding against measles-associated pneumonia [48], vitamin A supplementation has been examined as an accomplishable intervention in decreasing the severity as well as prevention against further episodes of acute lower respiratory tract infections [49-53]. In children with sufficient stores of vitamin $A$, an increased dose of vitamin A supplementation may result in transient malfunction in the regulation of immunomodulatory functions. This may further lead to a raised susceptibility to infectious diseases [54]. A study involving a systematic review about the function of vitamin A supplementation in the interference of respiratory tract infections among children have terminated their result as that supplements must only be provided to children having impaired nutritional status [55]. The mechanism by which vitamin A controls replication of measles is by upregulation of innate immune response in non-infected bystander cells and devising them unresponsive to fertile infection during later rounds of viral replication [56]. Hence vitamin A can be considered as a promising supportive option for the management of novel coronavirus and thereby hindering lung infection [57].

\section{Vitamin B}

$B$ vitamins are water-soluble and each of the B vitamins has specific functions. Vitamin B1 or thiamine is involved in glucose metabolism and is essential for the proper functioning of the nerve, heart, etc. B vitamins are involved in a wide range of functions, including activating innate adaptive immune responses, maintaining the integrity of endothelial cell layers, preventing hypercoagulation, enhancing respiratory functions as well as reducing proinflammatory cytokines [58]. The various B vitamins involved in immune-boosting effects include vitamin B1 (thiamine), vitamin B2 (riboflavin), vitamin B3 (nicotinamide), vitaminB5 (pantothenic acid), vitamin B6 (pyridoxal-5-phosphate and pyridoxine), vitamin B9 (folic acid), and vitamin B 12 (cyanocobalamin) [59].

\section{Vitamin C}

Otherwise called ascorbic acid, Vitamin C is also a water-soluble vitamin. Being soluble in water requires daily intake. It is also a 
relevant cofactor that plays a main role in cartilage and blood vessel formation. Vitamin C also has antioxidant properties which enable the protection of cells from the damage caused by free radicals. It also inhibits reactive oxygen species and helps in the cytokinin remodeling as well as safeguarding the essential biomolecules like lipids, proteins, etc. from oxidative damages [60]. Large doses of Vitamin C play a major role in wound healing and in enhancing immunity by aiding in the production and maturation of natural killer cells and T lymphocytes, engaged in antiviral responding. The daily recommended dose of vitamin C is $90 \mathrm{mg}$ for adult males and $75 \mathrm{mg}$ for adult females. Smokers require an additional dose of 35 mg daily [61]. A study in the culture of a tracheal organ of the chick embryo has shown increased resistance to the infection of the avian coronavirus after getting administered with vitamin C [62]. The regular use of vitamin $C$ has been shown to reduce the duration of a common cold. Under certain circumstances, vitamin C prevents susceptibility to lower respiratory tract infections also [63]. Vitamin C sometimes also functions as a weak antihistaminic agent and decreases the signs and symptoms related to flu-like sinus swelling, running nose, etc. and these antiviral properties of vitamin $C$ have paved the way for its use in fighting COVID 19 [64]. COVID 19 associated pneumonia has a higher rate of morbidity and mortality
[65]. Vitamin C is mainly effective in fighting Acute Respiratory Distress Syndrome associated with COVID 19. The antioxidant properties of vitamin $\mathrm{C}$ are effective in reducing oxidative stress. About $1.5 \mathrm{mg} / \mathrm{kg}$ vitamin $\mathrm{C}$ has been considered safe and was in use for decades. It is also reported that the use of vitamin $\mathrm{C}$ has significantly reduced the length of stay in the intensive care unit in novel coronavirus detected patients [66]. Also, the administration of $1.5 \mathrm{~g}$ vitamin $\mathrm{C}$ intravenously every $6 \mathrm{~h}$ showed a statistically significant reduction by about 30 percentages in the mortality rate of acute respiratory disease syndrome in patients with the condition of sepsis [67]. A clinical trial started in china is now in phase two to identify the effect of high dose vitamin $\mathrm{C}$ in ICU patients having covid associated severe pneumonia. About 2-10 g vitamin C per day IV infusion over 8-10 h was given to about 50 moderate to severe covid 19 infected patients in China and it was found that there was a relevant improvement in oxygen index in all the patients and all the patients significantly improved and got discharged [68]. The levels of vitamin C in the body of corona virus-infected patients significantly drop once sepsis develops. Hence it is so important to maintain vitamin C levels in the patient's body[69]. Vitamin C has proven viricidal, immunomodulatory as well as antioxidant properties as summarized in table 2 .

Table 2: Properties of vitamin C

$\begin{array}{ll}\text { Immunomodulatory effects } & \begin{array}{l}\text { Enhance proliferation, maturation, and differentiation of T lymphocytes } \\ \text { Anti-apoptotic activity on peripheral blood neutrophils } \\ \text { Raised immunoglobulin production }\end{array} \\ & \begin{array}{l}\text { Enhance the integrity of barriers of epithelial cells, which is the preliminary step in defencing outside } \\ \text { pathogens }\end{array} \\ & \text { Accumulate in neutrophils and enabling normal leukocyte functioning } \\ & \text { Improve the activity of phagocytes, natural killer cells, and chemotaxis of neutrophils } \\ \text { Anti Inflammatory effect } & \text { Decrease cytokine storm } \\ \text { Effect in critically ill patients } & \begin{array}{l}\text { Reduce the length of mechanical ventilation } \\ \text { Reduce hospital and ICU stay } \\ \text { Vasopressin requirements are reduced [69] }\end{array}\end{array}$

\section{Vitamin D}

Vitamin $\mathrm{D}$ is a prohormone and is generated in the skin on exposure to sunlight, ultraviolet B (UVB) rays of 290-315 nanometer. Also, a small quantity is obtained via food. In the case of people in areas lying in middle to high latitude, there will be an elevation in solar light during the winter season and hence sufficient production of vitamin $D$ is not possible due to the lack of UV B rays [76]. There is a huge global prevalence of lack of vitamin D levels among various populations and for most people, dietary supplementation may not be sufficient to provide adequate vitamin D levels [77]. Vitamin D plays a major role in preventing inflammatory responses in the pulmonary system and also enhances the innate defense pathways against the pathogens present in the respiratory system [78, 79]. There are reports that in a crosssectional study conducted among the US population, there is evidence of an association between lower levels of vitamin D and the occurrence of upper respiratory tract infections. The relation was more profound in the case of diseases like chronic obstructive pulmonary disease and asthma [80]. Also, there was evident relation between lower vitamin D levels and the development of acute respiratory tract infection [81]. The alarming spread of COVID 19 disease caused by the novel SARS $\mathrm{CoV} 2$ virus has raised the need to administer vitamin D supplements as a supporting therapy [82]. The use of vitamin D as a nutritional supplement in COVID 19 disease is based on presumed mechanisms. The first one is the use of Calcitriol, which is an active vitamin D hormone, has been highlighted in potentially treating avian influenza virus, (AVH5N1 virus) using accurate cell lines and mice upon screening certain repurposed drugs [83]. The second mechanism is based on the analysis made to relate vitamin $\mathrm{D}$ and viral infection [84]. Adaptive, natural cellular immunity and physical barrier mechanisms offered by vitamin D contribute to decreasing microbial-induced infections and death [85]. By taking into consideration, the facts that this covid outbreak occurred in the Winter season, the time when vitamin D levels are low, and that the deficiency can contribute to acute respiratory distress syndrome, which is related to the deficiency of $1,25(\mathrm{OH}) 2 \mathrm{D}$ concentration. Hence it is sensible to hypothesize that the use of vitamin D may enhance the immune responses in the host on the major organ systems [86].

\section{Zinc}

Zinc is an essential micronutrient and plays a major role in cellular metabolism, growth, synthesis of DNA. It is also involved in the formation, maintenance, and maturation of immune cells associated with innate as well as adaptive immunity. Deficiency in levels of zinc has been associated with the dysfunction of both humoral mediated and cellmediated immunity [87]. Therefore zinc can be provided in combination with other nutrients as supplements in covid 19 infected patients. There are reports that zinc supplementation can importantly reduce the morbidity and mortality associated with lower respiratory tract infections. A lower concentration combination of zinc and pyridine (zinc ionophore) can prevent SARS COV replication and hence can provide symptomatic relief in covid infected patients [88]. Studies have also shown that supplementation of zinc may reduce covid symptoms like respiratory tract infection and it might be due to blocking of uncoating, binding, and replication process of the virus. A case series involving 4 covid 19 positive patients who were provided with zinc supplementation in high doses had shown symptomatic improvement [89].

\section{Selenium}

Selenium, an essential trace element, can also be given as a general supportive treatment in fighting COVID 19. When the host is having an infectious disease, selenium deficiency can have an impact on both the host immune system as well as the pathogenic virus [90]. There are reports that the oxidative stress developed as a result of selenium deficiency can cause genomic changes in the virus and may sometimes result in a highly virulent virus in place of a normal mild or benign disease-causing virus [91]. RNA virus benign variants can also undergo fast mutations to highly virulent viruses [92]. Selenium and vitamin E combinations can be used to prevent the formation of 
free radicals and can thus reduce oxidative stress in cells and tissues. Selenium and saponins of ginseng stem leaf were found to have synergistic effects to generate immune responses to a live vaccine of bronchitis corona in chicken [93]. Various ongoing clinical trials aimed at demonstrating the protective role of vitamin $C$, vitamin $D$, zinc, and selenium are summarised in table 3 .

Table 3: Ongoing clinical trials to demonstrate the protective role of vitamin $C$, vitamin $\mathrm{D}$, zinc, and selenium

\begin{tabular}{|c|c|c|c|c|c|c|c|}
\hline $\begin{array}{l}\text { Clinical trial } \\
\text { number }\end{array}$ & $\begin{array}{l}\text { Started } \\
\text { date }\end{array}$ & Sponsor & $\begin{array}{l}\text { Study } \\
\text { participants }\end{array}$ & Study design & Intervention & Primary outcome & Ref \\
\hline NCT04335084 & $\begin{array}{l}\text { Jun } \\
2020\end{array}$ & USA & $\begin{array}{l}\text { Age } 18 \text { y and } \\
\text { older } \\
\text { male/female } \\
\text { healthy } \\
\text { volunteers }\end{array}$ & $\begin{array}{l}\text { The randomized, } \\
\text { interventional, } \\
\text { double-blind } \\
\text { study focuses on } \\
\text { medical workers } \\
\text { who are at } \\
\text { elevated risk of } \\
\text { COVID-19 }\end{array}$ & $\begin{array}{l}\text { Drug Hydroxychloroquine } \\
\text { (Plaquenil) with dietary } \\
\text { supplements such as Vit C, Vit } \\
\text { D, and Zinc for the prophylactic } \\
\text { treatment of COVID-19 }\end{array}$ & $\begin{array}{l}\text { Prevention of } \\
\text { COVID-19 }\end{array}$ & [94] \\
\hline NCT04334512 & $\begin{array}{l}\text { Jun } \\
2020\end{array}$ & USA & $\begin{array}{l}18 \text { y and older } \\
\text { with COVID-19 }\end{array}$ & $\begin{array}{l}\text { Randomized, } \\
\text { double-blind, } \\
\text { placebo- } \\
\text { controlled phase } \\
2 \text { interventional } \\
\text { study }\end{array}$ & $\begin{array}{l}\text { Quintuple therapy with } \\
\text { Hydroxychloroquine (Plaquenil) } \\
\text { and drug azithromycin with } \\
\text { dietary supplements such as Vit } \\
\text { C, Vit D, and Zinc }\end{array}$ & $\begin{array}{l}\text { Rate of recovery of } \\
\text { mild to moderate } \\
\text { patients }\end{array}$ & [95] \\
\hline NCT04344041 & $\begin{array}{l}\text { Apr } \\
2020\end{array}$ & France & $\begin{array}{l}\text { Age } 65 \text { y and } \\
\text { older with } \\
\text { COVID-19 }\end{array}$ & $\begin{array}{l}\text { Randomized, } \\
\text { controlled open- } \\
\text { label, parallel } \\
\text { study }\end{array}$ & $\begin{array}{l}\text { Vit D 400,000 IU in a single oral } \\
\text { dose }\end{array}$ & $\begin{array}{l}\text { Number of death } \\
\text { of any cause }\end{array}$ & [96] \\
\hline NCT04449718 & $\begin{array}{l}\text { Jun } \\
2020\end{array}$ & $\begin{array}{l}\text { University of } \\
\text { Sao Paulo } \\
\text { Brazil }\end{array}$ & $\begin{array}{l}240 \text { subjects } \\
\text { Age: } 18 \text { y and } \\
\text { older with the } \\
\text { diagnosis of flu } \\
\text { syndrome }\end{array}$ & $\begin{array}{l}\text { A randomized, } \\
\text { double-blind, } \\
\text { placebo- } \\
\text { controlled study }\end{array}$ & $\begin{array}{l}200,000 \text { IU of vitamin D3 on } \\
\text { admission }\end{array}$ & $\begin{array}{l}\text { There is no } \\
\text { significant } \\
\text { reduction in the } \\
\text { length of } \\
\text { hospitalization in } \\
\text { patients who } \\
\text { received a single } \\
\text { high dose of } \\
\text { vitamin D3 }\end{array}$ & [97] \\
\hline NCT04682574 & $\begin{array}{l}\text { Nov } \\
2020\end{array}$ & $\begin{array}{l}\text { University of } \\
\text { Lahore, } \\
\text { Pakistan }\end{array}$ & $\begin{array}{l}\text { Critically ill } \\
\text { patients } \\
\text { admitted to ICU }\end{array}$ & $\begin{array}{l}\text { A randomized, } \\
\text { parallel, open- } \\
\text { label study }\end{array}$ & $\begin{array}{l}\text { Vit C } 30 \mathrm{~g} \text { per day(10g TDS) for } \\
2 \mathrm{~d}\end{array}$ & $\begin{array}{l}\text { The partial } \\
\text { pressure of } \\
\text { oxygen in arterial } \\
\text { blood to the } \\
\text { fraction of } \\
\text { inspired oxygen }\end{array}$ & [98] \\
\hline NCT04357782 & $\begin{array}{l}\text { Apr } \\
2020\end{array}$ & $\begin{array}{l}\text { Hunter } \\
\text { Holmes } \\
\text { McGuire } \\
\text { Veteran } \\
\text { Affairs } \\
\text { medical } \\
\text { center USA }\end{array}$ & $\begin{array}{l}20 \text { participants: } \\
\text { age } 18 \text { to } 99 \mathrm{y} \text {, } \\
\text { hospitalized } \\
\text { with COVID-19 }\end{array}$ & $\begin{array}{l}\text { Non- } \\
\text { randomized, } \\
\text { open-label. } \\
\text { Parallel study }\end{array}$ & $\begin{array}{l}\text { L-ascorbic acid } 50 \mathrm{mg} / \mathrm{kg} \\
\text { infusion given every } 6 \text { to } 4 \mathrm{~h} \text { for } \\
4 \mathrm{~d}\end{array}$ & $\begin{array}{l}\text { Incidence of } \\
\text { adverse events }\end{array}$ & [99] \\
\hline NCT04636086 & $\begin{array}{l}\text { Nov } \\
2020\end{array}$ & $\begin{array}{l}\text { University of } \\
\text { Liege China }\end{array}$ & $\begin{array}{l}\text { Male and female } \\
18 \text { y and older } \\
\text { with COVID-19 }\end{array}$ & $\begin{array}{l}\text { A randomized, } \\
\text { double-blind, } \\
\text { controlled study }\end{array}$ & $\begin{array}{l}\text { One ampoule }(25,000 \\
\mathrm{IU} / \mathrm{ml}) \text { cholecalciferol given on } \\
\text { day } 1,2,3,4,8,15,22,29 \text { and } 36\end{array}$ & $\begin{array}{l}\text { Length of hospital } \\
\text { stay }\end{array}$ & {$[100]$} \\
\hline NCT04459247 & $\begin{array}{l}\text { Jun } \\
2020\end{array}$ & $\begin{array}{l}\text { PG Institute } \\
\text { of Medical } \\
\text { Education } \\
\text { and } \\
\text { Research, } \\
\text { India }\end{array}$ & $\begin{array}{l}\text { Asymptomatic or } \\
\text { mildly } \\
\text { symptomatic } \\
\text { SARS-CoV-2 RNA } \\
\text { positive with Vit } \\
\text { D deficiency }\end{array}$ & $\begin{array}{l}\text { The } \\
\text { randomized, } \\
\text { placebo- } \\
\text { controlled short } \\
\text { term study }\end{array}$ & 60000 IU cholecalciferol for $7 \mathrm{~d}$ & $\begin{array}{l}\text { Participants turned } \\
\text { to be SARS-CoV-2 } \\
\text { RNA negative, } \\
\text { followed by the } \\
\text { administration of } \\
\text { Vit D. }\end{array}$ & [101] \\
\hline NCT04334005 & $\begin{array}{l}\text { Apr } \\
2020\end{array}$ & $\begin{array}{l}\text { Universidad } \\
\text { de Granada, }\end{array}$ & $\begin{array}{l}200 \text { subjects } \\
\text { within the age } \\
\text { limit of } 40-70 y \text {, } \\
\text { both male and } \\
\text { female with mild } \\
\text { symptoms such } \\
\text { as cough, fever, } \\
\text { nasal congestion, } \\
\text { etc. }\end{array}$ & $\begin{array}{l}\text { Randomized, } \\
\text { parallel, double- } \\
\text { blinded study }\end{array}$ & Single-dose of 25000 UI of Vit D & $\begin{array}{l}\text { Total no of death } \\
\text { for any cause }\end{array}$ & [102] \\
\hline NCT04264533 & $\begin{array}{l}\text { Feb } \\
2020\end{array}$ & $\begin{array}{l}\text { Zhi Yong } \\
\text { Pang, China }\end{array}$ & $\begin{array}{l}140 \text { ICU patients, } \\
\text { Age 18years and } \\
\text { older male or } \\
\text { female diagnosed } \\
\text { with COVID-19 }\end{array}$ & $\begin{array}{l}\text { Randomized, } \\
\text { parallel, Triple } \\
\text { blinded study }\end{array}$ & $\begin{array}{l}12 \mathrm{~g} \text { Vit c IV infusion twice daily } \\
\text { for } 7 \mathrm{~d} \text {. }\end{array}$ & $\begin{array}{l}\text { Ventilation free } \\
\text { days }\end{array}$ & [103] \\
\hline NCT04323514 & $\begin{array}{l}\text { Mar } \\
2020\end{array}$ & $\begin{array}{l}\text { University of } \\
\text { Palermo, }\end{array}$ & $\begin{array}{l}500 \text { subjects of } \\
\text { any ages }\end{array}$ & $\begin{array}{l}\text { Uncontrolled } \\
\text { longitudinal, }\end{array}$ & $\begin{array}{l}10 \mathrm{~g} \text { Vit C IV in addition to } \\
\text { conventional therapy }\end{array}$ & $\begin{array}{l}\text { In-hospital } \\
\text { mortality }\end{array}$ & [104] \\
\hline
\end{tabular}




\begin{tabular}{|c|c|c|c|c|c|c|c|}
\hline & & Italy & $\begin{array}{l}\text { hospitalized } \\
\text { with COVID-19 } \\
\text { pneumonia }\end{array}$ & $\begin{array}{l}\text { Open-label, } \\
\text { single-group } \\
\text { study }\end{array}$ & & & \\
\hline NCT03680274 & $\begin{array}{l}\text { Nov } \\
2018\end{array}$ & $\begin{array}{l}\text { Universite } \\
\text { de } \\
\text { Sherbrooke, } \\
\text { Canada }\end{array}$ & $\begin{array}{l}800 \text { ICU patients, } \\
\text { age } 18 \text { y and } \\
\text { older, either male } \\
\text { or female } \\
\text { diagnosed with } \\
\text { COVID-19 and } \\
\text { receiving } \\
\text { continuous IV } \\
\text { infusion } \\
\text { vasopressors }\end{array}$ & $\begin{array}{l}\text { Randomized, } \\
\text { parallel, } \\
\text { quadruple } \\
\text { blinded study }\end{array}$ & Vit C $200 \mathrm{mg} / \mathrm{kg} /$ day IV & $\begin{array}{l}\text { Decreased } \\
\text { dependency for } \\
\text { mechanical } \\
\text { ventilation and } \\
\text { mortality }\end{array}$ & [105] \\
\hline NCT04386850 & $\begin{array}{l}\text { Apr } \\
2020\end{array}$ & $\begin{array}{l}\text { Tehran } \\
\text { University of } \\
\text { Medical } \\
\text { Science, Iran }\end{array}$ & $\begin{array}{l}1500 \text { CoVID-19 } \\
\text { positive patients }\end{array}$ & $\begin{array}{l}\text { Randomized, } \\
\text { parallel, } \\
\text { multicentre, } \\
\text { double-blinded } \\
\text { study }\end{array}$ & $\begin{array}{l}25 \text { mcg Vit D daily at bedtime } \\
\text { for } 2 \text { mo }\end{array}$ & $\begin{array}{l}\text { Rate, severity, and } \\
\text { duration of COVID }\end{array}$ & [106] \\
\hline NCT04411446 & $\begin{array}{l}\text { Aug } \\
2020\end{array}$ & $\begin{array}{l}\text { Vit D study } \\
\text { group, } \\
\text { Argentina }\end{array}$ & $\begin{array}{l}1265 \text { COVISD-19 } \\
\text { positive subjects, } \\
\text { Age } 18 \text { y and } \\
\text { older either male } \\
\text { or female }\end{array}$ & $\begin{array}{l}\text { Randomized, } \\
\text { parallel, } \\
\text { quadruple } \\
\text { blinded study }\end{array}$ & $\begin{array}{l}5 \text { capsules of } 100,000 \text { IU of Vit } \\
\text { D }\end{array}$ & $\begin{array}{l}\text { Organ failure } \\
\text { assessment and } \\
\text { need for } \\
\text { mechanical } \\
\text { ventilation }\end{array}$ & [107] \\
\hline NCT04363840 & $\begin{array}{l}\text { May } \\
2020\end{array}$ & $\begin{array}{l}\text { Louisiana } \\
\text { State } \\
\text { University } \\
\text { Health } \\
\text { Science } \\
\text { Center in } \\
\text { New Orleans, } \\
\text { USA }\end{array}$ & $\begin{array}{l}1080 \text { subjects, } \\
18 \text { y an older } \\
\text { male or female } \\
\text { newly diagnosed } \\
\text { with COVID-19 }\end{array}$ & $\begin{array}{l}\text { Randomized, } \\
\text { parallel, open- } \\
\text { label } \\
\text { assessment }\end{array}$ & $\begin{array}{l}\text { Vit D 50,000 IU once weekly } \\
\text { along with Aspirin } 81 \mathrm{mg} \text { once } \\
\text { daily for } 2 \mathrm{w}\end{array}$ & $\begin{array}{l}\text { Length of } \\
\text { hospitalization } \\
\text { and severity of } \\
\text { symptoms }\end{array}$ & [108] \\
\hline
\end{tabular}

\section{Iron}

Iron deficiency can lead to an increased risk of continual acute respiratory tract infection [109]. At the same time, iron overload can result in oxidative stress, which can ultimately result in dangerous mutations in the virus [110]. Hence iron in recommended doses can be given to deficient patients.

\section{Omega-3 polyunsaturated fatty acids}

Polyunsaturated fatty acids with long chains like omega 3, omega 6 polyunsaturated fatty acids play a major role in promoting antiinflammatory, proinflammatory as well as adaptive immune responses.
They are as well as precursors of protectins, prostaglandins, leukotrienes, etc. One of the major sources of omega 3 polyunsaturated fatty acid is fish oil. Some study reports studying plasma lipid levels in AIDS patients have shown a significant reduction of long-chain omega polyunsaturated fatty acids [111]. Also, studies showed that the use of a lipid derivative of omega 3 polyunsaturated fatty acid, called protectin D1, may inhibit the replication of viral particles by RNA export mechanism. Also, they exhibit activity against the hepatitis $C$ virus [112]. Thus these antiviral properties of omega polyunsaturated fatty acids may show a protective role in covid patients as well [113]. Apart from the nutrient supplements, some corona virus-specific treatments are mentioned in table 4 [114,115].

Table 4: Coronavirus specific treatments

\begin{abstract}
Antioxidant action, Herbacetin, Isobavachalcone etc can inhibit MERS-COV/3CL Pro Papain-like protease inhibitors

Diarylheptanoids-Obtained from the bark of Alnusjaponica

Spike (S) protein angiotensin-converting enzyme 2 blockers

\section{CONCLUSION}

The possible effects of various nutrient supplements like vitamin A, B, C, D, E, trace elements like zinc, selenium, and others like omega fatty acids on the immune system and the benefits in covid patients have been looked into. The established antiviral, immunomodulatory as well as anti-inflammatory effects of these nutrient supplements may help in reducing the complications associated. The benefits can be especially noted in the vulnerable population like the elderly and geriatrics who were presented with disproportionate morbidity as well as mortality rate.
\end{abstract}

Chymotrypsin like (3C) inhibitors, Flavonoids like Herbacelin, Pectolinarin, etc-inhibits 3C like protease

Can inhibit papain-like protease of SARS-COVID along with other natural components like cinanserin

ACE 2 receptor is a major active receptor of SARS-CoV. S protein mediates the viral entry as well as the fusion of viral-host

cells Blocking the interaction of ACE2 receptor and spike protein is therefore important

\section{FUTURE PERSPECTIVES}

All the supportive nutrient supplies which are mentioned above may demonstrate a protective role in the management of COVID-19 patients. However, clinical trials are ongoing to determine the benefits and effectiveness of supplementing the supportive therapy with nutrients in COVID patients. Hopefully, these studies may reveal and confirm the supportive role of nutrients in COVID 19 patients.

\section{FUNDING}

Nil

\section{AUTHORS CONTRIBUTIONS}

All authors have contributed equally.

\section{CONFLICT OF INTERESTS}

Declared none 


\section{REFERENCES}

1. Adhikari SP, Meng S, Wu YJ, Mao YP, Ye RX, Wang QZ, et al. Epidemiology, causes, clinical manifestation and diagnosis, prevention and control of coronavirus disease (COVID-19) during the early outbreak period: a scoping review. Infect Dis Poverty 2020;9:1-2.

2. Cai M, Wang C, Li Y, Gu H, Sun S, Duan Y, et al. Virus-like particle vaccine by intranasal vaccination elicits protective immunity against respiratory syncytial viral infection in mice. Acta Biochim Biophys Sin 2017;49:74-82.

3. Van Doremalen N, Bushmaker T, Morris DH, Holbrook MG, Gamble A, Williamson BN, et al. Aerosol and surface stability of SARS-CoV-2 as compared with SARS-CoV-1. N Eng J Med 2020;382:1564-7.

4. Chen Y, Liu Q, Guo D. Emerging coronaviruses: genome structure, replication, and pathogenesis. J Med Virol 2020;92:418-23.

5. Neuman BW, Adair BD, Yoshioka C, Quispe JD, Orca G, Kuhn P, et al. Supramolecular architecture of severe acute respiratory syndrome coronavirus revealed by electron cryomicroscopy. J Virol 2006;80:7918-28.

6. Li F. Structure, function, and evolution of coronavirus spike proteins. Annu Rev Virol 2016;3:237-61.

7. Kirchdoerfer RN, Cottrell CA, Wang N, Pallesen J, Yassine HM, Turner HL, et al. Pre-fusion structure of a human coronavirus spike protein. Nature 2016;53:118-21.

8. Walls AC, Tortorici MA, Bosch BJ, Frenz B, Rottier PJ, DiMaio F, et al. Cryo-electron microscopy structure of a coronavirus spike glycoprotein trimer. Nature 2016;53:114-7.

9. Holmes VK. SARS-associated coronavirus. $N$ Engl J Med 2003;348:1948-5.

10. Kampf G, Todt D, Pfaender S, Steinmann E. Persistence of coronaviruses on inanimate surfaces and their inactivation with biocidal agents. J Hosp Infect 2020;104:246-51.

11. Zou L, Ruan F, Huang M, Liang L, Huang H, Hong Z, et al. SARSCoV-2 viral load in upper respiratory specimens of infected patients. N Engl J Med 2020;382:1177-9.

12. Cheng VC, Wong SC, Chen JH, Yip CC, Chuang VW, Tsang OT, et al. Escalating infection control response to the rapidly evolving epidemiology of the coronavirus disease 2019 (COVID-19) due to SARS-CoV-2 in Hong Kong. Infect Control Hosp Epidemiol 2020;5:1-6.

13. Yuki K, Fujiogi M, Koutsogiannaki S. COVID-19 pathophysiology: a review. Clin Immunol 2020;215:108427.

14. Li W, Moore MJ, Vasilieva N, Sui J, Wong SK, Berne MA, et al. Angiotensin-converting enzyme 2 is a functional receptor for the SARS coronavirus. Nature 2003;426:450-4.

15. Chen Y, Guo Y, Pan Y, Zhao ZJ. Structure analysis of the receptor binding of 2019-nCoV. Biochem Biophys Res Commun 2020;525:135-40.

16. Zou X, Chen K, Zou J, Han P, Hao J, Han Z. Single-cell RNA-seq data analysis on the receptor ACE2 expression reveals the potential risk of different human organs vulnerable to 2019nCoV infection. Front Med 2020;14:185-92.

17. Yoshikawa T, Hill T, Li K, Peters CJ, Tseng CT. Severe acute respiratory syndrome (SARS) coronavirus-induced lung epithelial cytokines exacerbate SARS pathogenesis by modulating intrinsic functions of monocyte-derived macrophages and dendritic cells. J Virol 2009;83:3039-48.

18. Gurwitz D. Angiotensin receptor blockers as tentative SARS-CoV-2 therapeutics. Drug Dev Res 2020;81:1-4.

19. Cui S, Chen S, Li X, Liu S, Wang F. Prevalence of venous thromboembolism in patients with severe novel coronavirus pneumonia. J Thromb Haemost 2020;18:1421-4.

20. Zhang B, Zhou X, Zhu C, Song Y, Feng F, Qiu Y. Immune phenotyping based on the neutrophil-to-lymphocyte ratio and IgG level predicts disease severity and outcome for patients with COVID-19. Front Mol Biosci 2020;7:157.

21. Opal SM. Interactions between coagulation and inflammation. Scand J Infect Dis 2003;35:545-54.

22. Zheng YY, Ma YT, Zhang JY, Xie X. COVID-19 and the cardiovascular system. Nat Rev Cardiol 2020;17:259-60.

23. Gu J, Han B, Wang J. COVID-19: gastrointestinal manifestations and potential fecal-oral transmission. J Gastro 2020;158:1518-9.
24. Unhale SS, Ansar QB, Sanap S, Thakhre S, Wadatkar S, Bairagi R, et al. A review on coronavirus (COVID-19). WJPLS 2020;6:109-15.

25. Gao Z, Xu Y, Sun C, Wang X, Guo Y, Qiu S, et al. A systematic review of asymptomatic infections with COVID-19. J Microbiol Immunol 2021;54:12-6.

26. WHO. Clinical management of severe acute respiratory infection (SARI) when COVID-19 disease is suspected; 2020.

27. Singhal T. A review on coronavirus disease-2019(COVID-19). Indian J Pediatr 2020;87:281-6.

28. Huang C, Wang Y, Li X, Ren L, Zhao J, Hu Y. Clinical features of patients infected with 2019 novel coronavirus in Wuhan, China. Lancet 2020;395:497-506.

29. Wiersinga WJ, Rhodes A, Cheng AC, Peacock SJ, Prescott HC. Pathophysiology, transmission, diagnosis, and treatment of coronavirus disease 2019 (COVID-19): a review. JAMA 2020;324:782-93.

30. Sethuraman N, Jeremiah SS, Ryo A. Interpreting diagnostic tests for SARS-CoV-2. JAMA 2020;323:2249-51.

31. Wang W, Xu Y, Gao R, Lu R, Han K, Wu G, et al. Detection of SARS-CoV-2 in different types of clinical specimens. JAMA 2020;323:1843-4.

32. Goudouris ES. Laboratory diagnosis of COVID-19. J Pediatr 2021;97:7-12.

33. Deeks JJ, Dinnes J, Takwoingi Y, Davenport C, Spijker R, Taylor Phillips S, et al. Antibody tests for identification of current and past infection with SARS-CoV-2. Cochrane Database Syst Rev 2020;6:CD013652.

34. Shashank MP, Prithvi SS, Sujay S, Tejaswini M, Lakshmi VR, Jayanthi $M$, et al. The current status and perspectives for the emerging pandemic: covid-19. Int J Pharm Pharm Sci 2020;12:1-10.

35. Khan R, Irchhaiya R. In vitro in vivo evaluation of niosomal formulation of famotidine. Int J Pharm Pharm Sci 2020;1:15-22.

36. Hangargekar CB, Quazi RS, Joshi AA. A review on COVID-19-a global battle between life and death. Int J Curr Pharm Res 2020;12:19-24.

37. Chen G, Wu DI, Guo W, Cao Y, Huang D, Wang H. Clinical and immunological features of severe and moderate coronavirus disease 2019. J Clin Invest 2020;130:2620-9.

38. Gombart AF, Pierre A, Maggini S. A review of micronutrients and the immune system-working in harmony to reduce the risk of infection. Nutrients 2020;12:236.

39. Grant WB, Lahore H, McDonnell SL, Baggerly CA, French CB, Aliano JL, et al. Evidence that vitamin D supplementation could reduce risk of influenza and COVID-19 infections and deaths. Nutrients 2020;12:988.

40. Calder PC. Nutrition, immunity and COVID-19. BMJ Nutr Prev Health 2020;3:74.

41. Li G, Fan Y, Lai Y, Han T, Li Z, Zhou P, et al. Coronavirus infections and immune responses. J Med Virol 2020;92:424-32.

42. Huang $\mathrm{C}$, Wang $\mathrm{Y}$, Li X, Ren L, Zhao J, Hu Y, et al. Clinical features of patients infected with 2019 novel coronavirus in Wuhan, China. Lancet 2020;395:497-506.

43. Rothan HA, Byrareddy SN. The epidemiology and pathogenesis of coronavirus disease (COVID-19) outbreak. J Autoimmun 2020;109:102433.

44. Giamarellos Bourboulis EJ, Netea MG, Rovina N, Akinosoglou K, Antoniadou A, Antonakos $\mathrm{N}$, et al. Complex immune dysregulation in COVID-19 patients with severe respiratory failure. Cell Host Microbe 2020;27:992-1000.

45. Semba RD. Vitamin A and immunity to viral, bacterial and protozoan infections. Proc Nutr Soc 1999;58:719-27.

46. Jee J, Hoet AE, Azevedo MP, Vlasova AN, Loerch SC, Pickworth $\mathrm{CL}$, et al. Effects of dietary vitamin A content on antibody responses of feedlot calves inoculated intramuscularly with an inactivated bovine coronavirus vaccine. Am J Vet Res 2013;74:1353-62.

47. Dekker LH, Mora Plazas M, Marin C, Baylin A, Villamor E. Stunting associated with poor socioeconomic and maternal nutrition status and respiratory morbidity in colombian schoolchildren. Food Nutr Bull 2010;31:242-50.

48. Fawzi W, Mbise RL, Fataki MR, Herrera MG, Kawau F, Hertzmark E, et al. Vitamin supplementation and severity of pneumonia in children admitted to the hospital in Dar es Salaam, Tanzania. Am J Clin Nutr 1998;68:187-92. 
49. Julien MR, Gomes A, Varandas L, Rodrigues P, Malveiro F, Aguiar $\mathrm{P}$, et al. A randomized double-blind, placebo-controlled clinical trial of vitamin A in mozambican children hospitalized with non-measles acute lower respiratory tract infections. Trop Med Int Health 1999;4:794-800.

50. Nacul L, Kirkwood BR, Arthur P, Morris SS, Magalhães M, Fink MC. Randomized, double-blind, placebo-controlled clinical trial of efficacy of vitamin A treatment in non-measles childhood pneumonia. Br Med J 1997;315:505-10.

51. Rodriguez A, Hamer DH, Rivera J, Acosta M, Salgado G, Gordillo $\mathrm{M}$, et al. Effects of moderate doses of vitamin $\mathrm{A}$ as an adjunct to the treatment of pneumonia in underweight and normalweight children: a randomized, double-blind, placebocontrolled trial. Am J Clin Nutr 2005;82:1090-6.

52. Stevensen C, Franchi LM, Hernandez H, Campos M, Gilman RH, Alvarez JO. Adverse effects of high-dose vitamin A supplements in children hospitalized with pneumonia. Pediatrics 1998;101:1-8.

53. Cameron C, Dallaire F, Vezina C, Muckle G, Bruneau S, Ayotte P, et al. Neonatal vitamin A deficiency and its impact on acute respiratory infections among preschool Inuit children. Can J Public Health 2008;99:102-6.

54. Grotto I, Mimouni M, Gdalevich M, Mimouni D. Vitamin A supplementation and childhood morbidity from diarrhea and respiratory infections: a meta-analysis. J Paediatr 2003;142:297-304.

55. Chen H, Zhuo Q, Yuan W, Wang J, Wu T. Vitamin A for preventing acute lower respiratory tract infections in children up to seven years of age. Cochrane Database Syst Rev 2008;23:CD006090.

56. Trottier C, Colombo M, Mann KK, MillerWH Jr, Ward BJ. Retinoids inhibit the measles virus through a type I IFN-dependent bystander effect. FASEB J 2009;23:3203-12.

57. Chen Y, Liu Q Guo D. Emerging coronaviruses: genome structure, replication, parthenogenesis. J Med Virol 2020;92:418-23.

58. Michele CA, Angel B, Valeria L, Teresa M, Giuseppe C, Giovanni $\mathrm{M}$, et al. Vitamin supplements in the Era of SARS-Cov2 pandemic. GSC Biol Pharm Sci 2020;11:7-19.

59. Shakoor H, Feehan J, Mikkelsen K, Al Dhaheri AS, Ali HI, Platat C, et al. Be well: a potential role for vitamin B in COVID-19. Maturitas 2021;144:108-11.

60. Magrì A, Germano $G$, Lorenzato $A$, Lamba $S$, Chilà R, Montone $M$, et al. High-dose vitamin $C$ enhances cancer immunotherapy. Sci Transl Med 2020;12:532.

61. Truwit JD, Hite RD, Morris PE, DeWilde C, Priday A, Fisher B, et al. Effect of vitamin $\mathrm{C}$ infusion on organ failure and biomarkers of inflammation and vascular injury in patients with sepsis and severe acute respiratory failure: the CITRIS-ALI randomized clinical trial. JAMA 2019;322:1261-70.

62. Atherton JG, Kratzing CC, Fisher A. The effect of ascorbic acid on infection chick-embryo ciliated tracheal organ cultures by coronavirus. Arch Virol 1978;56:195-9.

63. Hemila H. Vitamin C intake and susceptibility to pneumonia. Pediatr Infect Dis J 1997;16:836-7.

64. Field CJ, Johnson IR, Schley PD. Nutrients and their role in host resistance to infection. J Leukoc Biol 2002;71:16-32.

65. Hunt C, Chakravorty NK, Annan G, Habibzadeh N, Schorah CJ. The clinical effects of vitamin $C$ supplementation in elderly hospitalised patients with acute respiratory infections. Int J Vit Nutr Res 1994;64:212-9.

66. Hemila H, Chalker E. Vitamin $\mathrm{C}$ can shorten the length of stay in the ICU: a meta-analysis. Nutrients 2019;11:708.

67. Colunga Biancatelli RM, Berrill M, Marik PE. The antiviral properties of vitamin C. Exp Rev Anti Ther 2020;18:99-101.

68. Marik PE, Khangoora V, Rivera R, Hooper MH, Catravas J. Hydrocortisone, vitamin $\mathrm{C}$, and thiamine for the treatment of severe sepsis and septic shock: a retrospective before-after study. Chest 2017;151:1229-38.

69. Korah MC, Pv JR, Rajeswari R, Behanan A, Paul EP, Sivakumar T. Adverse effects and side effects on vitamin therapy: a review. Asian J Pharm Clin Res 2017;10:19-26.

70. Ferron Celma I, Mansilla A, Hassan L, Garcia Navarro A, Comino $\mathrm{A}$, Bueno $\mathrm{P}$, et al. Efect of vitamin $\mathrm{C}$ administration on neutrophil apoptosis in septic patients after abdominal surgery. J Surg Res 2009;153:224-30.
71. Carr A, Maggini S. Vitamin C and immune function. Nutrients 2017;9:1211.

72. Liugan $\mathrm{M}$, Carr A. Vitamin $\mathrm{C}$ and neutrophil function: findings from randomized controlled trials. Nutrients 2019;11:2102.

73. Heuser G, Vojdani A. Enhancement of natural killer cell activity and $\mathrm{T}$ and $\mathrm{B}$ cell function by bufered vitamin $\mathrm{C}$ in patients exposed to toxic chemicals: the role of protein kinase-C. Immunopharmacol Immunotoxicol 1997;19:291-312.

74. Wang Y, Lin H, Lin B, Lin J. Efects of diferent ascorbic acid doses on the mortality of critically ill patients: a meta-analysis. Ann Intensive Care 2019;9:58.

75. Lakshmi VS, Menon RB, Raju K, Aiswarya M, Nair SC. Formulation and evaluation of lorazepam encapsulated collagen/pectin buccal patch. Int J Appl Pharm 2019;7:200-9.

76. Webb AR, Kline L, Holick MF. Influence of season and latitude on the cutaneous synthesis of vitamin D3: exposure to winter sunlight in Boston and Edmonton will not promote vitamin D3 synthesis in human skin. J Clin Endocrinol Metab 1988;67:373-8.

77. Bouillon R. Vitamin D status is worse in Africa than in other continents. Lancet 2019;8:e20-1.

78. Hughes DA, Norton R. Vitamin D and respiratory health. Clin Exp Immunol 2009;158:20-5.

79. Zdrenghea MT, Makrinioti H, Bagacean C, Bush A, Johnson SL, Stanciu LA. Vitamin D modulation of innate immune responses to respiratory viral infections. Rev Med Virol 2017;27:1-3.

80. Ginde AA, Mansbach JM, Camargo CA. Association between serum 25-hydroxyvitamin D level and upper respiratory tract infection in the third national health and nutrition examination survey. Arch Intern Med 2009;169:384-90.

81. Laaksi I, Ruohola JP, Tuohimaa P. An association of serum vitamin D concentrations $<40 \mathrm{nmol} / \mathrm{l}$ with acute respiratory tract infection in young Finnish men. Am J Clin Nutr 2007;86:714-7.

82. Grant WB, Lahore H, McDonnell SL. Evidence that vitamin D supplementation could reduce risk of influenza and COVID-19 infections and deaths. Nutrients 2020;12:E988.

83. Huang $\mathrm{F}$, Zhang $\mathrm{C}$, Liu Q. Identification of amitriptyline $\mathrm{HCl}$, flavin adenine dinucleotide, azacitidine and calcitriol as repurposing drugs for influenza A H5N1 virus-induced lung injury. PLoS Pathog 2020;16:e1008341.

84. Lee C. Controversial effffects of vitamin D and related genes on viral infections, pathogenesis, and treatment outcomes. Nutrients 2020;12:962.

85. Zhou W, Liu Y, Tian D, Wang C, Wang S, Cheng J, et al. Potential benefits of precisecorticosteroids therapy for severe 2019nCoV pneumonia. Signal Transduct Target Ther 2020;5:1-3.

86. Gautret P, Lagier JC, Parola P, Meddeb L, Mailhe M, Doudier B, et al. Hydroxychloroquine and azithromycin as a treatment of COVID-19: results of an open-labelnon-randomized clinical trial. Int J Antimicrob Agents 2020;56:105949.

87. Maares M, Haase H. Zinc and immunity: an essential interrelation. Arch Biochem Biophys 2016;611:58-65.

88. Awotiwon AA, Oduwole 0 , Sinha A, Okwundu CI. Zinc supplementation for the treatment of measles in children. Cochrane Database of Syst Rev 2017;6:CD011177.

89. Finzi E. Treatment of SARS-CoV-2 with high dose oral zinc salts: a report on four patients. Int J Inf Dis 2020;99:307-9.

90. Beck MA, Matthews CC. Micronutrients and host resistance to viral nfection. Proc Nutr Soc 2000;59:581-5.

91. Guillin OM, Vindry C, Ohlmann T, Chavatte L. Selenium, selenoproteins and viral infection. Nutrients 2019;11:2101.

92. Harthill M. Review: micronutrient selenium deficiency influences the evolution of some viral infectious diseases. Biol Trace Elem Res 2011;143:1325-36.

93. MaX, BiS, Wang Y, Chi X, Hu S. Combined adjuvant effect of ginseng stem-leaf saponins and selenium on immune responses to a live bivalent vaccine of Newcastle disease virus and infectious bronchitis virus in chickens. Poult Sci 2019;98:3548-56.

94. Shakoor H, Feehan J, Al Dhaheri AS, Ali HI, Platat C, Ismail LC, et al. Immune-boosting role of vitamins D, C, E, zinc, selenium and omega-3 fatty acids: could they help against COVID-19? Maturitas 2020;143:1-9.

95. Parra Lara LG, Martine Arboleda JJ, Rosso F. Aithromycin and SARS-CoV-2 infection: where we are now and where we are going. J Glob Antimicrob Resist 2020;22:680-4. 
96. Chandran M, Maung AC, Mithal A, Parameswaran R. Vitamin D in COVID-19: dousing the fire or averting the storm?-A perspective from the Asia-Pacific. Osteoporos Sarcopenia 2020;6:97-105.

97. Murai IH, Fernandes AL, Sales LP, Pinto AJ, Goessler KF, Duran CSC, et al. Effect of a single high dose of vitamin D3 on hospital length of stayin patients with moderate to severe COVID-19 a randomied clinical trial. JAMA 2021;325:1053-60.

98. Philipp S, Claudia G, Ulrich K. Supplementation of the population during the COVID-19 pandemic with vitamins and micronutrients-how much evidence is needed. Swiss Med Wkly 2021;151:w20522.

99. Name JJ, Souza ACR, Vasconxelos AR, Prado PS, Pereira CPM. Zinc, vitamin d and vitamin c: perspectives for COVID-19 with a focus on physical tissue barrier integrity. Front Nutr 2020;7:606398.

100. Shakoor H, Feehan J, Al Dhaheri AS, Cheikh IL, Ali HI, Alhebshi $\mathrm{SH}$, et al. Role of Vitamin D supplementation in aging patients with COVID-19. Maturitas 2021;S0378-5122:00041-44.

101. Rastogi A, Bhansali A, Khare N, Suri V, Yaddanapudi N, Sachdeva $\mathrm{N}$, et al. Short term, high-dose vitamin D supplementation for COVID-19 disease: a randomised, placebocontrolled, study (SHADE study). Postgrad Med J 2020. DOI:10.1136/postgradmedj-2020-139065

102. Panfili FM, Roversi M, Argenio PD, Rossi P, Cappa M, Fintini D. Possible role of vitamin D in Covid-19 infection in pediatric population. J Endocrinol Invest 2021;44:27-35.

103. Carr AC, Rowes $\mathrm{S}$. The emerging role of vitamin $\mathrm{C}$ in the prevention and treatment of COVID-19. Nutrients 2020;12:3286.

104. Jamali Moghadam Siahkali S, Zarezade B, Koolaji S, Seyed Alinaghi S, Zendehdel A, Taberestani M, et al. Safety and effectiveness of high-dose vitamin $C$ in patients with covid-19: a randomized openlabel clinical trial. Eur J Med Res 2021;26:20.

105. Gosain R, Abdou Y, Singh A, Rana N, Puzanov I, Ernstoff MS. COVID-19 and cancer: a comprehensive review. Curr Oncol Rep 2020;22:1-5.

106. Monpara JD, Sodha SJ, Gupta PK. COVID-19 associated complications and potential therapeutic targets. Eur J Pharmacol 2020;886:173548

107. Mohan M, Cherian JJ, Sharma A. Exploring links between vitamin D deficiency and COVID-19. PLoS Pathog 2020;16:e1008874.
108. Diaz T, Trachtenberg BH, Abraham SJ, Kosagi Sharaf R, Durant Archibold AA. Aspirin bioactivity for prevention of cardiovascular injury in COVID-19. Front Cardiovasc Med 2020;7:317.

109. Jayaweera J, Reyes M, Joseph A. Childhood iron deficiency anemia leads to recurrent respiratory tract infections and gastroenteritis. Sci Rep 2019;9:12637.

110. Wessling Resnick M. Crossing the iron gate: why and how transferrin receptors mediate viral entry. Annu Rev Nutr 2018;38:431-58.

111. Thayyilakandy S, Arjun KK, Krishnakumar G, Gayathri PS, Nair SC. A futuristic perspective in subsiding symptoms of Parkinson's disease. Int J Res Pharm Sci 2019;10:975-89.

112. S Shefrin, Sreelaxmi CS, Joseph S, Nair SC. A glance preface and novel approaches for the efficient treatment of a migraine. Int J Res Pharm Sci 2019;10:282-97.

113. Sundaram MN, Mony U, Varma PK, Jayakumar R. Vasoconstrictor and coagulation activator entrapped chitosan based composite hydrogel for rapid bleeding control. Carbohydr Polym 2021;258:117634.

114. Rogero MM, Leao MD, Santana TM, de MB Pimentel MV, Carlini GC, da Silveira TF, et al. Potential benefits and risks of omega-3 fatty acids supplementation to patients with COVID-19. Free Radical Biol Med 2020;156:190-9.

115. Arya GK, Kumar AA, Nair AJ, Raju J. Nanodisc: a new epoch in the study of membrane proteins and as an emerging drug delivery system. Int J Appl Pharm 2019;11:1-6.

116. Sreedhar R, Kumar VS, Bhaskaran Pillai AK, Mangalathillam S. Omega-3 fatty acid-based nanolipid formulation of atorvastatin for treating hyperlipidemia. Adv Pharm Bull 2019;9:271-80.

117. Zhang L, Liu Y. Potential interventions for novel coronavirus in China: a systematic review. J Medvirol 2020;92:479-90.

118. Park JY, Jeong HJ, Kim JH, Kim YM, Park SJ, Kim D, et al. Diarylheptanoids from Alnus japonica inhibit papain-like protease of severe acute respiratory syndrome coronavirus. Biol Pharm Bull 2012;35:2036-42.

119. Warner FJ, Smith AI, Hooper NM, Turner AJ. Angiotensinconverting enyme-2: a molecular and cellular perspective. Cell Mol Life Sci 2004;61:2704-13. 